\title{
Teacher's Strategies of Teaching English toward Students in Inclusive Classrooms during Pandemic Covid-19
}

\author{
Ely Heldydiana Selamat ${ }^{1}$, Hildegardis Oktaviani Angkut ${ }^{1}$ \\ English Language Education Department, Faculty of teaching and education, University catholic \\ Indonesia saint paul Ruteng \\ \{ely.heldydiana@gmail.com, hildegardis.oktaviani@gmail.com \}
}

\begin{abstract}
In teaching English as a Foreign language in schools, the EFL teachers are expected to be able to select and apply teaching strategies that are suitable to their student's needs. The case of teaching English to the students in inclusive classrooms becoming one of the big problems faced by the EFL teacher. They have to design the lesson plan well as their students have consisted of both regular and disabled students. This condition becomes more challenging in this pandemic covid-19 era because the EFL teachers have to design all the activities and instructions through virtual meetings using any kind of online learning application. Thus, the aim of this descriptive qualitative method research was to uncover the EFL teachers' strategies used in teaching English to the students in inclusive classrooms. The EFL teachers are interviewed about their experiences in teaching the inclusive classroom during the pandemic covid-19, particularly, teaching English virtually. The result of this study helps the researchers to have a clear picture of strategies used by the EFL teachers in inclusive classrooms.
\end{abstract}

Keywords: EFL Teachers, Teaching English, Online Learning, Inclusive Classroom

\section{Introduction}

Inclusive classroom is a classroom in a regular school building, and a seat in an ageappropriate general education classroom. The inclusive classroom differs from a homogeneous classroom in one special way. The needs of the students are more obvious, for an example, in teaching learning process, the blind students use their own tools to write down all the subjects. The inclusive classroom is the way to help those who get kinds of any physical defect to learn in the classroom learning. The inclusive classroom is designed to put disable learners for joining the class with the normal students (Pijl and Hegart 1997,106-107).

Good and qualified teachers are essential for the efficient functioning of educational systems and for enhancing the quality of learning.[13] has supported this notion in research and explained that a good teacher and actions to be taken on his/her part in the classroom play a vital role in provoking effective and efficient learning on the part of the students. Teachers also have a fundamental role in their learners' academic achievement and their quality have to be able to highly influence the student outcomes [4]. In the world of language teaching and learning, and especially after the advent of Communicative Language Teaching (CLT), there appears to be a general consensus on the maximal use of target language in the language classes, and the desirability of the target language as the medium of teaching is emphasized [5]. 
Apart from the use of the target language in the English as a foreign language (EFL) in the classroom, the appropriate level of difficulty for students should also be considered [16]. Thus, this also concerns teachers' competency in teaching and learning. Teaching and learning process takes place in the classroom where the teacher interacts with the students. Doyle, as quoted by [10], states that the classroom is a unique place unit in which the teacher and students interact for the purpose of teaching and learning to take place. For this, classroom is a place which is functioned as the place where the interaction between teacher and students happened. Thus, a teacher has to create an effective and conducive environment that can achieve the goals of the student, planning the activities, monitoring discipline, and reaching students' motivation in learning.

Nowadays, the EFL teachers are challenged to be more creative for the emergence of covid19. This virus has affected many fields of peoples' lives including the education field. The interaction between teacher and students changed from in-person class into an online class. The previous research which has been done by Atmojo and Nugroho [1] revealed that many problems emerged from the teachers, students, and even from students' parents along with various reasons due to the pandemic covid-19. The teachers have insufficient knowledge on how to carry out online learning.

Furthermore, the students were lack of facilities of smartphones, internet quota, and unstable internet connection. Similar findings were found by Nartiningrum \& Nugroho [15] who found that the unsteady network and the less direct interactions become the problems that EFL teachers and students faced during this online class. Additionally, the strategies in teaching students in an inclusive classroom are essential. Teachers ought to try to apply strategies that will meet the needs of children with special needs and lesson learning difficulties as well as behaviour, social or emotional problems. The way as the useful strategy for the inclusive classroom is effective teaching, through this strategy teachers are capable of requires many tools in the teaching- learning process in the inclusive classroom. Polloway[16] planned the other strategy in the inclusive classroom is peer tutoring, this strategy will help the students in inclusive classroom learning together with their friends in the classroom.

The shifting of in-person class to online learning hit the EFL teachers' strategies in teaching-learning process not only in regular school but also the schools which served the students with special needs. As an inclusive classroom, the students consist of regular and special needs students, the teacher has to have his/ her own strategies in coping with the different needs of the students, for instance, the blind, deaf or physical sickness. The teachers must be able to design and plan the instructions well to achieve the students' different needs in the classroom.

Thus, the EFL teachers' difficulties and strategies in teaching the students in the inclusive classroom have been examined by many researchers. More recently, the previous research done by Kurniati [11] showed that the EFL teacher use different strategies to students with special needs when teaching in English for normal students the teacher asks them to write test but for student's special needs they just ask and answer the questions verbally without written test. Thus, does the teachers, who are educate with inclusion produce and create diverse learners, have to be confident in what diversity and inclusion truly mean, their confidence spread among the children, creating a welcoming environment that respects all areas of diversity Webster. Nevertheless, the new problems raised from this pandemic covid-19 that teacher and students in inclusive classroom interact virtually.

Recent study was done by balileyand lee) [2] found that native EFL teachers in South Korea who have experienced in designing online instructions seemed to face no challenge than the EFL teachers who were not. For this, the teachers with no experience using online teaching have 
to be introduced to the learning management system (LMS) discussion forum and cloze ended questions. In light of teaching English to the students in an inclusive classroom, that is very few previous researchers examined the strategies the EFL teachers used in their teaching-learning process during this pandemic covid-19. Thus, this current study will focus on exploring the EFL teachers' strategies of using online platforms in teaching the students in inclusive classrooms.

\section{Research Methods}

This study was a case study conducted at three different schools in Ruteng, Flores-East Nusa Tenggara, Indonesia. These three schools were the school that applied inclusive education where the students with special needs might acquire and learned English together with regular students. As the data were collected during this pandemic covid-19, the 6(six) experienced EFL teachers were interviewed individually through the Video and audio call in the WhatsApp application. In collecting the data, the researcher has interviewed 6 respondents of 3 females and 3 males. For this academic year, there are 4 classes for the inclusive classroom in three different schools, but in one class there are only 1-3 students with special needs, and it is also not all the classes.

In general, the characteristics of students in inclusive classrooms are different in terms of gender. For these students with special needs, they have certain conditions, such as totally blind, physical and mental retardation as well as students with down syndrome. In terms of needs, they are heterogeneous. The interview was mostly about their experiences on how they taught English virtually. The semi-structure interviewee was administered to get as much as detailed information from the teachers. The interviews were recorded, saved in audio format, and transcribed to be analysed further. To get the necessary data accordingly to the current research objective, the interview recording, and transcript were read several times. Then the unrelated data were deleted. Finally, to validate the result both researchers discussed times to reach the final agreement about the result.

\section{Results and Discussion}

After interviewed all the respondents, the researcher drew main themes based on their answers. The following detail of themes analysed was as the result of the interviews from the English teachers under the title is EFL teachers' strategies in teaching students inclusive classrooms during this pandemic.

For the first question, the researcher was asking about the experiencing of EFL teachers in teaching English in an Inclusive classroom. Overall, they have been teaching English in inclusive classroom starting from 2-8 years.

"2 years" \& "8 years"

For this section, the researcher asked about the opinion about E-learning, particularly in an inclusive classroom.

Interviewer: It is not easy, cause half of them didn't have to support the facilities such as handphone/laptop

Interviewer: it's difficult, course from the students with special needs and without special needs they have different approaches even in normal situations, so far for disabilities students they do the task from teachers good, even they work it from home. It depends on the teachers 
how to make students understand the materials that gave by the teachers. GC and WAG are some platforms that teachers used to send the material or to collect the task. During this pandemic, we still have some problems. Almost of the students in inclusive class some of them have physically and mentally problem, all of the students live in the same place in a boarding house so they can help each other. But Sometimes having meetings directly but just for few students who didn't understand clearly. However, the other just having interaction in GC of WAG. Helping each other can solve the problem.

The third question was asking about the kind of strategies that EFL teachers applied in inclusive classes to help them in teaching-learning process during this pandemic covid 19. Strategies in the classroom as the important thing to be able to handle the classroom. Based on the result of the interview there are two kinds of strategies that teachers used to teach English during this pandemic.

Classical or group approach put them in the group even in normal situations. The Individual approach calls them one by one, make something like counselling, interview, a simple quiz to building up their skills, their knowledge, brainstorming.

Fourth was asking about the opinion of EFL teachers with using the appropriate strategies used in teaching English in an inclusive classroom. And the important thing is communication or interaction between teachers and students.

Interaction, for both of the strategies above we can have WAG or google classroom, by using voice notes or giving some video, pictures related to the materials. For example, teachers give them the picture and then they can make some description text according to the picture but before that the teachers can give the videos to improve the knowledge related to the materials. Interaction by using videos, audio, and pictures.

In this section, the researcher would like to discuss the result of the interview. The list of interviews consisted of seventh questions. The purpose of this descriptive qualitative method research was to uncover the EFL teachers' strategies used in teaching English to the students in inclusive classrooms. The purpose of this study was to find out the research problems was: what are the EFL teachers' strategies in teaching students inclusive classrooms during this pandemic. The findings from this research answered the research question very similarly.

Based on the finding above, those teachers have answered about what are the teacher's strategies on English e-learning inclusive class during pandemic covid-19. Some of the students have mental problems and also physical problems. Challenges include relating pedagogies with technologies, designing interactive activities, enhancing formal learning, gaining students' support, and dealing with problems in the use of technology [18]. But with the many challenges and difficulties so far students with special needs can know what they are going to do, how they can do and how they can send or collect their task. By helping each other in their boarding house.

Sometimes if they don't understand at all, the teachers can ask them to meet directly with the teachers one by one then teachers will guide them to understand the materials. The platforms that the teachers used to send the materials or tasks are Google Classroom and WhatsApp Group. In using this platform, the teachers will send a picture or videos related to the materials then ask the students to describe the picture and videos. For example, the teachers give them the picture about animals and then they make some description text.

Other strategies that the teachers used are the Classical or group approach and the Individual approach. For this strategy the classical or group approach, the teachers will put them into some groups to discuss the materials or the task use WAG \& GC and it can make the teaching-learning process easier when they work or learn together. An individual educational course is a focused educational program that provides the student with the position of the subject 
of choice, development, and implementation of the educational standard when the teacher provides pedagogical support, self-determination, and self-realization [7].

In this individual approach, the teachers will call them one by one, to make something like counselling, interview, make simple quizzes to building up their skills, their knowledge, brainstorming and to make them understand clearly related to materials. With this interaction also the teachers can know well about students' difficulties or problems with their learning. And the teachers have their own way or strategies to solve that problem in teaching students' inclusive classrooms during this pandemic. Moreover, student-teacher and student-material interactions have significant and positive effects on students' satisfaction. Thus, teachers need to scaffold interactions of student-teacher and student-material to enhance students' learning [3].

\section{Conclusion}

Based on the result above there are some strategies that the teachers used for the students with special needs, first is classical or group approaches second is individual approaches. For the classical or group approach, the teachers will put them into some groups to discuss the materials or the task using WAG or GC and for the individual approach, the teachers will call them one by one, to make something like counselling, interview, make simple quizzes. Besides that also students with special needs helping each other in their teaching-learning process and teachers make more interaction like counselling, interviews, make simple quizzes to building up their skills, their knowledge, and also brainstorming.

\section{References}

[1] Atmojo, E.P. A,\&Arif N.(2020). EFL Classes Must Go Online! Teaching Activitiesand Challenges during COVID-19 Pandemic inIndonesia. IAIN Surakarta. Vol. 13, No. 1, (2020), pp.49-76

[2] Bailey, D. R. \& Lee, K. R. (2020). Learning from Experience in the Midst of Covid-19: Benefits, Challenges, and Strategies in Online Teaching. Computer-Assisted Language Learning Electronic Journal, 21(2), 178-198.

[3] Cao, W., Fang, Z., Hou, G., Han, M., Xu, X., Dong, J., \& Zheng, J. (2020). The Psychological Impact of the COVID-19 Epidemic on College Students in China. Psychiatry Research, 287, 15.https://doi.org/10.1016/j.psychres.2020.112934

[4] Champell, R..,kyriakides, L. Muijsc, R. D \& Robinsona, W. (2004). Effective Teaching and values : some Implications for research and teacher appraisal. Oxford review of education $30(4,451465$

[5] Crawford, J. 2004. Language choises in the foreign Language classroom: Target language or the learners' first language?. RELC Journal. 35(1), 5-20

[6] Dhlamini, J., \& Mogari, D. (2013). The effect of a group approach on the performance of high school mathematics learners. Pythagoras, 34(2), Art. 198, 9 pages.

[7] Daria Pavlenko et al./Procedia Computer Science 169.(2020). Individual approach to knowledge control in learning management system. National Research Nuclear University MEPhI, Kashirskoe shosse 31, Moscow 115409, Russian Federation259-263

[8] Gonzalez, D., \& Louis, R. St. (2018). Online Learning. In J. I. Liontas (Ed.),The TESOL Encyclopedia of English Language Teaching (1st ed.). https://doi.org/10.1002/9781118784235.eelt0423

[9] Green, P. (2016). How to Succeed with Online Learning. In N. Rushby \& D. W. Surry (Eds.), The Wiley Handbook of Learning Technology (1st ed., pp. 261-286). https://doi.org/10.1002/9781118736494.ch15 
[10] Khine, Mynt S.,et al. 2005. Classroom Management: Facilitating Teachers and Learning. Singapore: Pearson Prentice Hall

[11] Kurniati, M.A (2019).The difficulties and strategies EFL experience in inclusive classroom. Mei 2020.UNIKA ST PAULUS RUTENG:Ruteng.

[12] Krish, P. (2008). Language Learning in the Virtual World: Instructors' Voices.International Journal of Pedagogies and Learning, 4(4), 113-129. https://doi.org/10.5172/ijpl.4.4.113

[13] Markley, T. (2004). Defining the effective teacher: Current arguments in education. Essays in Education, 11(3), 1-14.

[14] McGhie-Richmond, Underwood \& Jordan.(2007). Developing Effective instructional Strategies for Teaching in inclusive Classrooms. Exceptionality Education Canada, 2007, Vol. 17, No. 1

[15] Nartiningrum, Novrika.(2020). Online Learning amidst Global Pandemic: EFL Students'Challenges, Suggestions, and Needed Materials.University of Muhammadiyah Malang, Indonesia: Surakarta

[16] Polio, C. G., \& Duff, P. A. (1994). Teachers' language use in university Fireign Language classroom: a qualitative analysis of English and target language alternation. The modern language journal. 78(3), 313-326

[17] Smith, T. E., Polloway, E. A, Patton, J.R, Dowdy, C. A., \& Doughty, T. T. (2014). Teaching Students with SpeciAL NEEDS in inclusive settings. Upper Saddle River, NJ: Pearson.

[18] Son, J. (2018). Technology in English as a Foreign Language (EFL) Teaching. In J. I. Liontas (Ed.), The TESOL Encyclopedia of English Language

[19] Teaching (1st ed.). https://doi.org/10.1002/9781118784235.eelt0448

[20] Sun, S. Y. H. (2014). Learner Perspectives on Fully Online Language Learning. Distance Education, 35(1), 18-42. https://doi.org/10.1080/01587919.2014.891428

[21] Utami,T.P.2020. An analysis of teachers'strategies on englishe-learning classes during covid-19 pandemic. Salatiga: Teacher Training And Education FacultyState Institute For Islamic Studies (Iain)

[22] Yazcayir, G., \& Gurgur, H. (2021). Students with Special Needs in Digital Classrooms during the COVID-19 Pandemic in Turkey.Pedagogical Research, 6(1), em0088. https://doi.org/10.29333/pr/9356 